\title{
Students' Responses toward Scientific Argumentation with ADI Learning Model to Physics Literacy: A Case of Indonesian Senior High School Students
}

\author{
D S Bestiantono ${ }^{1}$ \\ ${ }^{1}$ Department of Physics, Faculty of Mathematics and Natural Science, Universitas Negeri Surabaya, Surabaya \\ 60231, Indonesia
}

\section{Article Info \\ Article history: \\ Received March 18, 2020 \\ Revised April 11, 2020 \\ Accepted April 13, 2020}

Keywords:

Scientific Argumentation

ADI

RT-SAPL

Indonesian

Students

\begin{abstract}
The aim of this study is to explore Indonesian students' responses towards scientific argumentation with ADI learning model to physics literacy by using survey study. The sample included 100 Indonesian senior high school students (47\% male and 53\% female) who were studying at public school in East Java province. The Responses towards Scientific Argumentation ADI Learning Model to Physics Literacy (RT-SAPL) questionnaire was developed with Indonesian language and validated through an exploratory factor analysis of participants' responses. For measuring the correlation among three dimensions of scale, the Pearson Correlation product moment was used. The findings indicated: the instrument used in this study had satisfactory validity and reliability. Meanwhile, the construct validities of the RT-SAPL were varying from .617 and .832 and extracting $70.655 \%$ of the variance with overall Cronbach's alpha constant was .854 . Moreover, the dimension of ADI learning model came in the first rank and followed by Scientific argumentation as well as the degree of responses towards scientific argumentation with ADI learning model to physics literacy. Finally, the findings have also indicated a significant relationship among factors of RT-SAPL.
\end{abstract}

\section{INTRODUCTION}

Curriculum 2013 is oriented towards $21^{\text {st }}$ century learning. The $21^{\text {st }}$ century learning model stresses the capability of learners to find out from various sources, formulate problems, think collaboratively and analytically to solve problems (Kemendikbud, 2013). According to (Doringin, 2017) $21^{\text {st }}$ century skills are able to strengthen social capital and intellectual capital; this is commonly abbreviated as $4 \mathrm{C}$ : collaboration, communication, critical thinking, and problem solving, as well as creativity and innovation. In (Kulsum \& S. E Nugroho, 2014) stated that the curriculum currently being developed makes the student centered learning process, in line with the $21^{\text {st }}$ century learning paradigm that requires students to have thinking and learning skills. One of the skills that need to be developed is critical thinking skills.

One indicator that indicates that a student has critical thinking skills is being able to analyze, understand, and evaluate arguments in learning activities. This is in line with the opinion (Harrell, 2004) which states that "critical thinking involves the ability to analyze, understand, and evaluate an argument".

This is in line with the fundamental foundation of the importance of the scientific argumentation skills stated by (Osborne, Erduran, Simon, \& Mork, 2004). The following are some important points of scientific argumentation skills in learning science:

$\checkmark$ Create the existence of cognitive and metacognitive processes in accordance with the performance characteristics of experts who can become figures for students.

$\checkmark$ Support the development of competencies and critical thinking skills of students. 
$\checkmark$ Supports increased scientific literacy skills and trains students to speak and write in scientific languages.

$\checkmark$ Supports acculturation in the practice of scientific culture and develops epistemic criteria for evaluating knowledge.

$\checkmark$ Supports the development of reasoning in particular the selection of theories or the determination of attitudes based on rational criteria.

Science literacy according to (PISA, 2016) is defined as "the ability to use scientific knowledge, identify questions, and draw conclusions based on evidence, in order to understand and make decisions regarding nature and changes made to nature through human activities". This definition, views scientific literacy as multidimensional, namely students' understanding of the characteristics of science as scientific inquiry, awareness of the importance of science and technology in shaping the material, intellectual and cultural environment, and the desire to be involved in science-related issues, as a reflective human being.

Furthermore, the term scientific literacy will be written as physics literacy, bearing in mind that the subject in this paper is focused in the field of physics which is a branch of science. Understanding, dimensions, and measurements of physics literacy as a whole adopt from scientific literacy.

Based on the rationale above, the aim of the current study is to explore the Indonesian students' responses towards scientific argumentation with ADI learning model to physics literacy. For details, the purposes of this study were three points:

1. To examine the validity and reliability of Responses Towards Scientific Argumentation with ADI Learning Model to Physics Literacy Questionnaire (RTSAPL).

2. To explore the degree of responses towards scientific argumentation with ADI learning model to physics literacy among senior high school students.

3. To examine the relationships among factors of attitudes towards ADI Learning Model, Scientific Argumentation, and Physics Literacy.

\section{RESEARCH METHOD}

Starting from October to November 2019, the author delivered the questionnaire via traditional survey method to students in three classes' senior high schools in East Java province, Indonesia. "Survey designs are procedures in quantitative research in which investigators administer a survey to a sample to describe the attitudes, the opinion, behaviors or characteristics of population" (Creswell, 2014). Explicitly, the survey is a useful method to assess Scientific Argumentation Learning education programs on students' responses towards Physics Literacy. Figure 1 illustrates the research procedure. 
Existing items and scales were surveyed by literature review, adapting, and developing

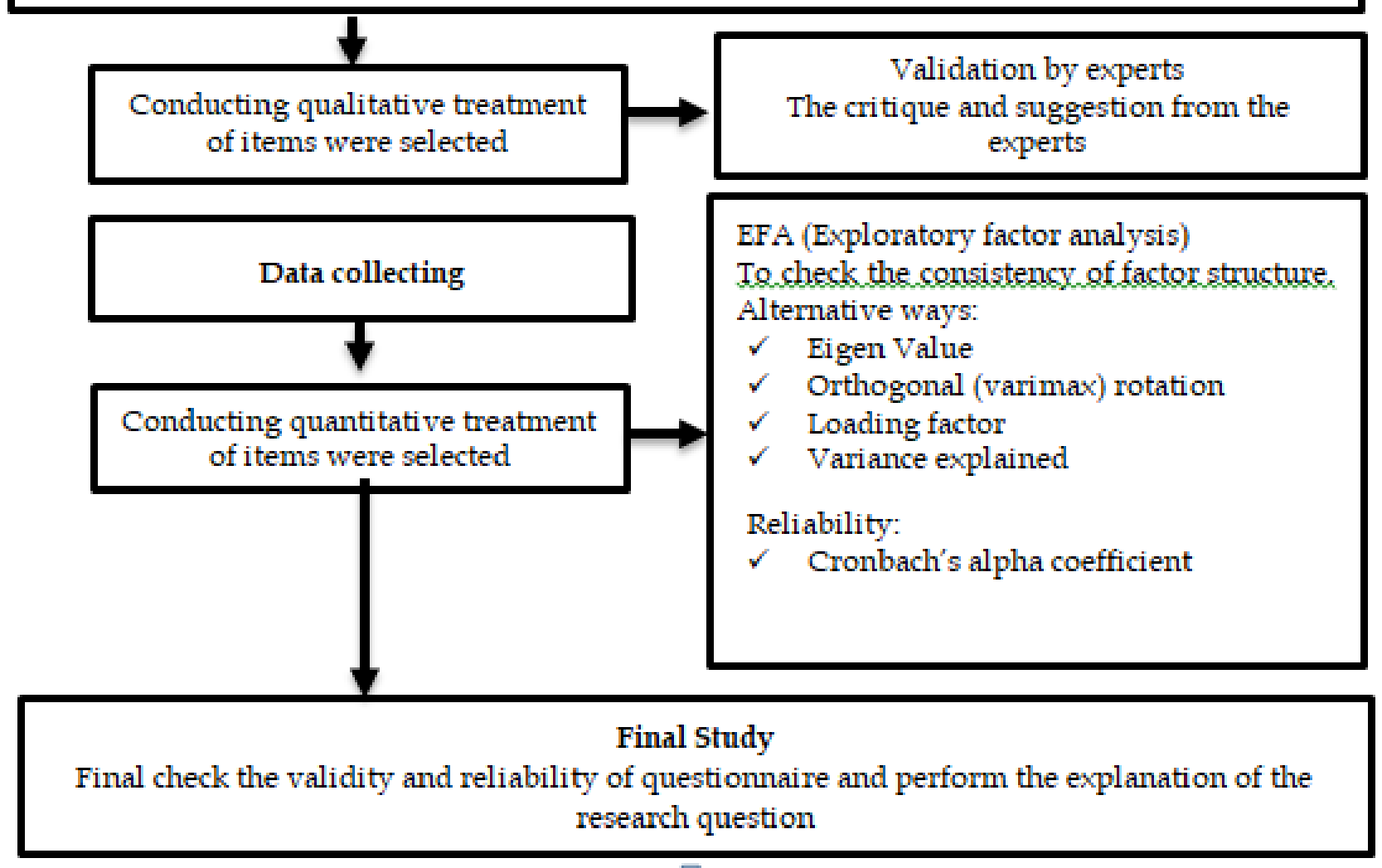

Figure 1. The process of survey study in this research adopted (Suprapto, 2016)

\section{RESULTS AND DISCUSSION}

\section{a) Exploratory Factor Analysis of RT-SAPL}

For validating the RT-SAPL instrument, an EFA over and done with a varimax rotation was performed to clarify the structure of scale. From 12 items performed the Kaiser-MeyerOlkin (KMO) value was .911 and the result of Bartlett's test was significant $\left(X^{2}=734,070, p<\right.$ $.000)$, indicating that the samples were suitable for factor analysis. The next step, the samples' responses were separated into the following three planned factors-(1) ADI learning model (ADI), (2) scientific argumentation (SA), and (3) physics literacy (PL), - and a total of 12 items were retained in the RT-SAPL instrument.

The detailed descriptions of the three factors are depicted as follows: 1. ADI learning model (ADI, four items): exploring the students' responses towards motivation, learning objectives, the benefits of learning, and aspect. 2. Scientific argumentation (SA, four items): exploring the students' responses towards indicators of scientific argumentation, assessment aspect of argumentation, benefits of argumentation, the essence of scientific argumentation. 3. Physics literacy (PL, four items): exploring the students' responses towards the essence of physics literacy, physics literacy competence, attitudes towards science, and criteria for scientific knowledge.

Meanwhile, the eigenvalues of the three dimensions from the principal component analysis (PCA) were all larger than one, and the total variance extracted was $70.655 \%$, which 
clarifying the structure of the scale. The factor of ADI learning model itself can describe the highest variance with achieved $58.21 \%$. It means the students was activated and motivated in participating in learning, can help students to develop a scientific argumentation in accordance with its components and with good quality, can help students to increase cooperation between group members, and can help students deliver arguments both verbally or written. This factor is in accordance with ADI learning objectives to improve students' physical literacy abilities. Moreover, the internal reliability for these factors was $.772, .782, .617$, and .778 , based on the Cronbach's alpha coefficients, with the overall alpha value was .815. It means all factors had high internal consistency for evaluating the participants' three dimensions of responses towards SAPL.

Table 1. The result of EFA analysis of the RT-SAPL questionnaire

\begin{tabular}{|c|c|c|c|}
\hline & $\begin{array}{c}\text { Factor 1: } \\
\text { ADI }\end{array}$ & $\begin{array}{c}\text { Factor 2: } \\
\text { SA }\end{array}$ & $\begin{array}{c}\text { Factor 3: } \\
\text { PL }\end{array}$ \\
\hline \multicolumn{4}{|c|}{ Factor 1 : ADI Learning Model, $\alpha=.815$, variance explained $=58.21 \%$} \\
\hline$A D I 1$ & .772 & & \\
\hline ADI 2 & .782 & & \\
\hline ADI 3 & .617 & & \\
\hline ADI 4 & .778 & & \\
\hline \multicolumn{4}{|c|}{ Factor 2 : Scientific Argumentation, $\alpha=.854$, variance explained $=6.73 \%$} \\
\hline SA 1 & & .802 & \\
\hline SA 2 & & .715 & \\
\hline SA 3 & & .795 & \\
\hline$S A 4$ & & .832 & \\
\hline \multicolumn{4}{|c|}{ Factor $3:$ Physics Literacy, $a=.828$, variance explained $=5.72 \%$} \\
\hline PL 1 & & & .746 \\
\hline PL 2 & & & .761 \\
\hline PL 3 & & & .730 \\
\hline PL 4 & & & .802 \\
\hline
\end{tabular}

Note: Total variance explained $=70.655 \%$ and Overall Cronbach's $\alpha=.832$.

\section{b) The Degree of Responses Towards ADI Learning Model, Scientific Argumentation,} and Physics Literacy

Table 2 presents the degree of responses towards ADI learning model, scientific argumentation, and physics literacy. The factor of ADI learning model came in the first position with a mean and standard deviation of $(3.24 ; 0.52)$ followed by Scientific argumentation $(3.14 ; 0.59)$. Meanwhile, the physics literacy appeared in the last position with a means and standard deviation of $(3.10 ; 0.56)$. This finding specified that ADI learning model became the central preference item and following by scientific argumentation compared to Physics literacy itself. This result represents the proportion of ADI learning model has greater value than others in this research. 
Table 2. Summary of the degree of attitude towards ADI, Scientific Argumentation, and Physics Literacy

\begin{tabular}{lccc}
\hline \multicolumn{1}{c}{ Dimension } & M & SD & Rank \\
\hline Argument-Driven Inquiry (ADI) & $3.24^{*}$ & 0.52 & 1 \\
Scientific Argumentation (SA) & 3.14 & 0.59 & 2 \\
Physics Literacy (PL) & 3.10 & 0.56 & 3 \\
\hline Mean & 3.16 & 0.56 & \\
\hline
\end{tabular}

${ }^{*}$ mean > grand mean

c) The relationships among students' responses towards ADI, scientific argumentation, and physics literacy

The value of Factor Loading which is formed from the effect of the application of scientific argumentation with the Argument-Driven Inquiry model to the physics literacy of students is in the range of $0.617-0.832$. The application of scientific argumentation with the ADI model to students' physics literacy influences 3 factors, namely the ADI model, scientific argumentation (SA) and physics literacy (PL) with a total effect of $70.655 \%$.

\section{DISCUSSION}

This research was focused on investigating the Indonesian senior high school students' responses towards scientific argumentation with ADI learning model to physics literacy. Explicitly, the study explored the degree of responses towards ADI learning model, scientific argumentation, and physics literacy, and surveyed the relationships among its factors. Supported by two physics teachers, then the study was started by introducing and demonstrating teaching and learning process and integrating argumentation learning model with topic "Heat and Temperature".

Generally, the findings designated that the RT-SAPL instrument had satisfactory validity and reliability. The scale performed well based on its variance explained $(70.65 \%)$. Additionally, the overall of Cronbach's alpha coefficient was .832 also indicated the high reliability. It could be said that the instrument can be used for further study, especially for other level which adopting argumentation learning model.

The factor of ADI learning model itself came in the first position and tailed by scientific argumentation as a component of argumentation learning model implied that scientific argumentation is a basic knowledge of taking foundation to the Physics literacy. At the senior high school level (grade 10-12), instruction in science especially Physics are usually talking about numerical knowledge. Thought the ability of argumentation is much needed in learning process. These findings also in-lined with (Osborne, Erduran, Simon, \& Monk, 2001), "First, it is important to point out that by 'argument' we do not mean the pejorative use of the word with its confrontational connotations. We mean the putting forward of reasons where claims are justified by relating them to the data on which they are based. Evidence for any claim consists of at least two components - data and warrants". Patterns of scientific argumentation that are analyzed using a framework (Sampson \& Gleim, 2009) are illustrated in Figure 2. 


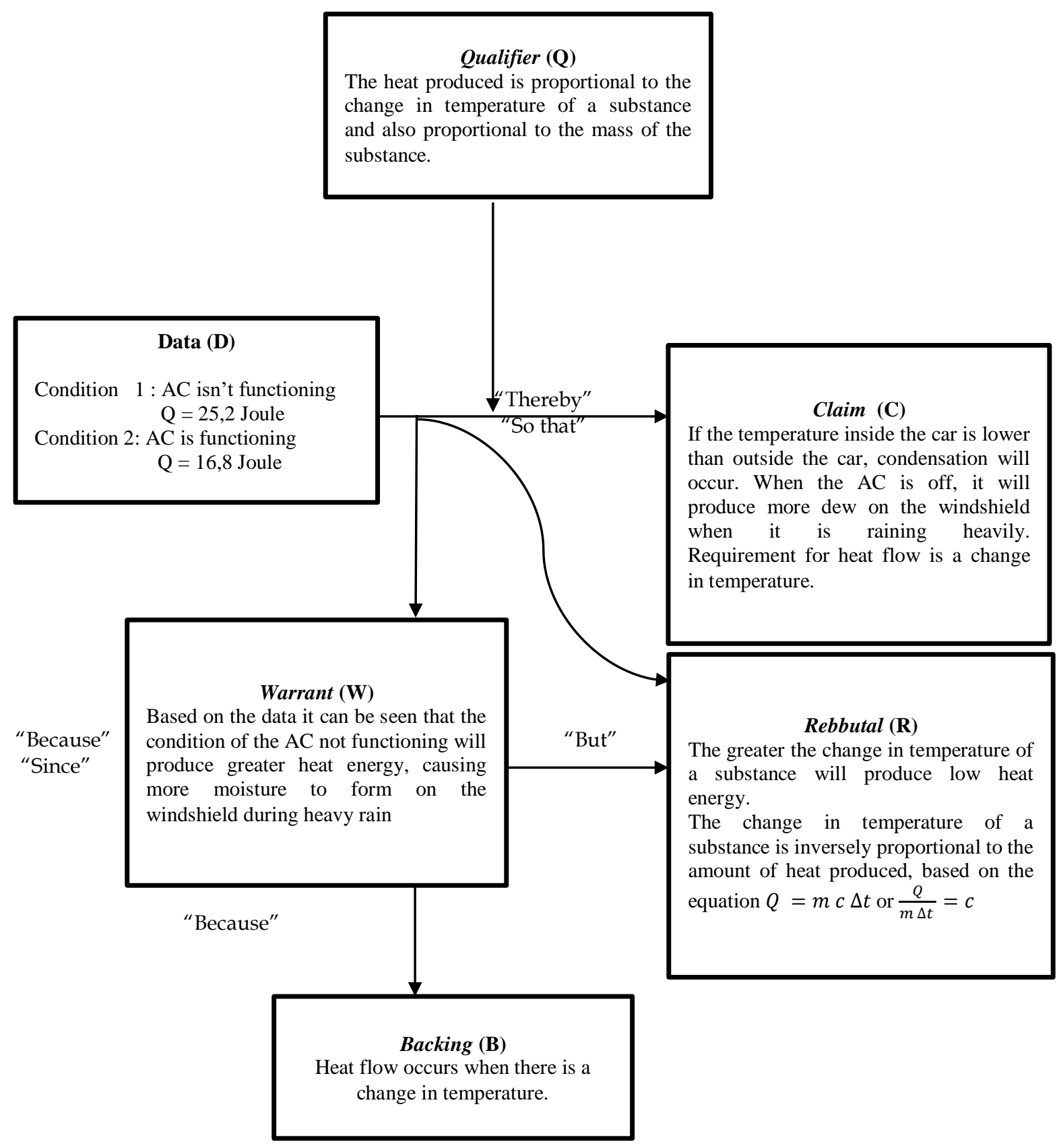

Figure 2. Argumentation pattern

If we discussing about the relationships among three factors, there were significant relationships among the three dimensions of RT-SAPL: ADI Learning Model (ADI), Scientific Argumentation (SA), and Physics Literacy (PL). Overall the items included in the ADI factor are in accordance with the theory made. The ADI learning model factor explains that by applying this learning, students can become more active and motivated in participating in learning, can help students to develop a scientific argumentation in accordance with its components and with good quality, can help students to improve collaboration between group members, and can help students convey arguments both verbally and in writing. This factor is in accordance with ADI learning objectives to improve students' physical literacy abilities. 
Scientific argumentation factor describing learning with an argumentation pattern makes students able to provide an idea (claim), analyze data based on claims, and provide rational justification based on theory, with scientific arguments train students to be able to say (verbally) and write (written) with the language of science, investigation and argumentation sessions carried out to make students more understanding and prolong the process of memory, and learning with an argumentation pattern makes students able to validate or reject an idea (claim) based on scientific reasons and reflect the behavior of scientists.

Physics literacy factor describes students feeling to be able to include the relationship between science issues and scientific ideas in a reflective way in life, make students able to explain phenomena scientifically, evaluate and design scientific investigations, and interpret data and scientific evidence, make scientific learners have a motivational attitude in science, scientific learning beliefs, support in scientific inquiry, and responsibility for resources and the environment, and make students more interested in learning physics because the phenomena provided in learning are relevant to real situations, are important knowledge so its use is long-term.

\section{CONCLUSION}

Through this research, there are some conclusions: (1) the RT-SAPL instrument had satisfactory validity and reliability; (2) the factor of ADI Learning Model came in the first rank and followed by Scientific Argumentation and Physics Literacy; and (3) there was a significant relationship among factors of responses towards ADI learning model, scientific argumentation, and physics literacy. Scientific argumentation becomes a benchmark in physics learning process. Learning in curriculum 2013 is oriented towards the $21^{\text {st }}$ century skills. The skills are able to strengthen social capital and intellectual capital; this is commonly abbreviated as 4C: communication, collaboration, critical thinking and problem solving, as well as creativity and innovation. Meanwhile, the curriculum currently being developed makes the student centered learning process, that requires students to have thinking and learning skills. One of the skills that need to be developed is critical thinking through scientific argumentation.

\section{ACKNOWLEDGEMENTS}

This paper is part of Bachelor thesis, therefore the author gives many thanks to Mr. Nadi Suprapto, Ph.D. as a supervisor who has provided many suggestions, motivations, assistance, and moral education during manuscript preparation. Special thanks are also dedicated to High School 1 Jombang students, especially students of class XI Science 1, XI Science 3, and XI Science 4, who have agreed to be a sample in this research.

\section{REFERENCES}

Creswell, J. (2014). Research design pendekatan kualitatif, kuantitatif dan mixed. Yogyakarta: Pustaka Pelajar.

Doringin, F. (2017). https://pgsd.binus.ac.id/2017/08/08/kurikulumbaru-keterampilan-abad-21-danimplementasinya/. Retrieved September 09 17, 2019, from https://pgsd.binus.ac.id .

Harrell, M. (2004). Using argument diagrams to improve critical thinking skills in introductory philosophy. Carnegie Mellon University Department of Philosophy, 3.

Kemendikbud. (2013). Peraturan Menteri Pendidikan dan Kebudayaan Republik Indonesia Nomor 65 Tahun 2013 Tentang Standar Proses Pendidikan Dasar dan Menengah. Kemendikbud.

Kulsum, U., \& S. E Nugroho. (2014, Agustus). Penerapan model pembelajaran cooperative problem solving untuk meningkatkan kemampuan pemahaman konsep dan 
komunikasi ilmiah siswa pada mata pelajaran fisika. Unnes Physics Education Journal, 2.

Osborne, J., Erduran, S., Simon, S., \& Monk, M. (2001, June). Enhancing the quality of argument in school science. School Science Review, 63.

Osborne, J., Erduran, S., Simon, S., \& Mork, M. (2004, June). Enhancing the quality of argument in school science. Journal of Research in Science Teaching, 994-1020.

PISA. (2016). PISA 2015. [Online]. doi:Available at: www.oecd.org

Sampson, V., \& Gleim, L. (2009). Argument-Driven Inquiry to promote the understanding of important concepts \& practices in biology. The American Biology Teacher, 71, 465-472.

Suprapto, N. (2016). Student's Attitude towards STEM education : Voice from Indonesian Junior High School. Journal of Turkish Science Education, 13(Special Issue), 75-87.

\section{APPENDIX \\ Item Responses towards Scientific Argumentation ADI Learning Model to Physics Literacy (RT-SAPL) Questionnaire}

\begin{tabular}{|c|c|c|c|c|c|c|}
\hline \multirow[t]{2}{*}{ Code } & \multirow[t]{2}{*}{ Items } & \multicolumn{5}{|c|}{ Option } \\
\hline & & SD & $\mathbf{D}$ & $\mathbf{N}$ & $\mathbf{A}$ & SA \\
\hline ADI & Argument-Driven Inquiry & & & & & \\
\hline ADI 1 & $\begin{array}{l}\text { I became more active and motivated to } \\
\text { take part in learning by applying the } \\
\text { ADI learning model. }\end{array}$ & & & & & \\
\hline ADI 2 & $\begin{array}{l}\text { Learning done with the ADI model can } \\
\text { help me to develop a scientific } \\
\text { argumentation in accordance with its } \\
\text { components and with good quality. }\end{array}$ & & & & & \\
\hline ADI 3 & $\begin{array}{l}\text { The application of the ADI learning } \\
\text { model can enhance collaboration } \\
\text { between group members. }\end{array}$ & & & & & \\
\hline ADI 4 & $\begin{array}{l}\text { Learning done with the ADI model can } \\
\text { help me convey arguments both } \\
\text { verbally and in writing. }\end{array}$ & & & & & \\
\hline SA & Scientific Argumentation & & & & & \\
\hline SA 1 & $\begin{array}{l}\text { Learning with argumentation patterns } \\
\text { makes me able to provide an idea } \\
\text { (claim), analyze data based on claims, } \\
\text { and provide rational justification based } \\
\text { on theory. }\end{array}$ & & & & & \\
\hline SA 2 & $\begin{array}{l}\text { With the existence of scientific } \\
\text { arguments train me to be able to say } \\
\text { (oral) and write (written) with the } \\
\text { language of science. }\end{array}$ & & & & & \\
\hline SA 3 & $\begin{array}{l}\text { Investigations and argumentation } \\
\text { sessions conducted made me better } \\
\text { understand and prolong the memory } \\
\text { process. }\end{array}$ & & & & & \\
\hline SA 4 & $\begin{array}{l}\text { Argumentation learning allows me to } \\
\text { validate or reject an idea (claim) that is } \\
\text { based on scientific reasons and reflects }\end{array}$ & & & & & \\
\hline
\end{tabular}


the behavior of scientists.

\begin{tabular}{|c|c|c|c|c|c|c|}
\hline \multirow[t]{2}{*}{ Code } & \multirow[t]{2}{*}{ Items } & \multicolumn{5}{|c|}{ Option } \\
\hline & & SD & $\mathbf{D}$ & $\mathbf{N}$ & $\mathbf{A}$ & SA \\
\hline PL & Physics Literacy & & & & & \\
\hline PL 1 & $\begin{array}{l}\text { Literacy based learning (physics) makes } \\
\text { me have the ability to include the } \\
\text { relationship between science issues and } \\
\text { science ideas in a reflective way in life. }\end{array}$ & & & & & \\
\hline PL 2 & $\begin{array}{l}\text { Learning based on scientific literacy } \\
\text { (physics) makes me able to explain } \\
\text { phenomena scientifically, evaluate and } \\
\text { design scientific investigations, and } \\
\text { interpret data and scientific evidence. }\end{array}$ & & & & & \\
\hline PL 3 & $\begin{array}{l}\text { Learning based on scientific literacy } \\
\text { (physics) makes me have a motivational } \\
\text { attitude in science, confidence in } \\
\text { learning science, support in scientific } \\
\text { inquiry, and responsibility for resources } \\
\text { and the environment. }\end{array}$ & & & & & \\
\hline PL 4 & $\begin{array}{l}\text { The phenomena provided in learning } \\
\text { are relevant to real situations, are } \\
\text { important knowledge so that their use } \\
\text { is long-term, and makes me more } \\
\text { interested in learning science (physics). }\end{array}$ & & & & & \\
\hline
\end{tabular}

\section{Corresponding Author:}

Della Shinta Bestiantono

Department of Physics, Faculty of Mathematics and Natural Science,

Universitas Negeri Surabaya,

Jl. Ketintang, Surabaya 60231, Indonesia

Email: dsbestiantono@gmail.com 